\title{
The effects of fiscal decentralization on household income inequality: some empirical evidence ${ }^{(*)}$
}

\author{
Agnese Sacchi \\ Department of Economics, University of Roma Tre, Rome (Italy) \\ E-mail: asacchi@uniroma3.it \\ Simone Salotti \\ Department of Economics, National University of Ireland, Galway (Ireland) \\ E-mail: simone.salotti@nuigalway.ie
}

\begin{abstract}
In this paper we investigate the effects of fiscal decentralization on income inequality using a sample of 23 OECD countries over the period 1971-2000. We utilize novel and robust measures of fiscal decentralization based on different degrees of expenditure and tax autonomy of sub-central governments. We also use several different specifications to tackle the potential endogeneity and reverse causality issues. Our results highlight the importance both of the nature of fiscal decentralization - expenditure versus taxation - and of the extent to which responsibility and decision powers are actually assigned to local governments. An important finding is that a higher degree of tax decentralization is associated with higher household income inequality within a country. This suggests that even if fiscal decentralization could be attractive according to efficiency reasons, it may actually have undesirable consequences on the equity side.
\end{abstract}

Keywords: tax decentralization, expenditure decentralization, household income inequality.

JEL classification: H70, H77, D31, R12

$\left(^{*}\right)$ We would like to thank Paolo Liberati, Giovanna Messina, Stephen O'Neill, Marzia Romanelli, Antonio Scialà, Carmine Trecroci and the participants in the workshop on "Fiscal Decentralization" held at the Bank of Italy (Rome, 14-15 November 2011) and in the workshop on "Inequality and Regional Growth and Cohesion" held at the University of Barcelona (Barcelona, 24-25 November 2011) for helpful comments and suggestions. All remaining errors are our responsibility. 


\section{Introduction}

Fiscal decentralization is the process through which powers over expenditures/revenues are delegated from the central government to the sub-central levels of government (both local and intermediate tiers). The extent of fiscal decentralization depends on the ability of lower tiers of government to make independent revenue and expenditure decisions within their geographic domain, without interference by the central government (Martinez-Vazquez and McNab 1997). Starting from the 80s, many developed countries have increased their degree of fiscal decentralization (Rodden 2003; OECD 2006, 2009a, 2009b; Bodman and Hodge 2010). Indeed, in Europe - on top of the already federalized Austria, Germany, and Switzerland-Belgium, Italy, and Spain have recently introduced widespread reforms in order to enhance regional autonomy (Ezcurra and Rodriguez-Pose 2010). France and Poland have taken more limited steps towards regionalization by creating regions and directly elected assemblies. The UK and Portugal opted for some forms of devolution and transferred a considerable amount of powers to their regions. Australia and Canada have also experienced modest increases to their already significant levels of decentralization. A study published by the World Bank (1999) argues that localization (i.e., the increasing demand for local autonomy), alongside globalization, is the main force shaping the world in the first decade of the $21^{\text {st }}$ century (see also Gemmell et al. 2009).

The international debate on the advantages and disadvantages of promoting fiscal decentralization usually focuses on efficiency, and there are many studies devoted to the investigation of how decentralization influences a number of economic variables. A non-comprehensive list includes government size (either at local or aggregate levels), regional and national economic growth and development, the degree of economic integration and trade openness, government and public institutions quality. For instance, Bird and Wallich (1993) affirm that reforms aimed at increasing fiscal decentralization are often justified by the widespread belief that it effectively improves the efficiency of public expenditures by creating competition among sub-national governments in delivering public services.

An important question that has been to some extent disregarded by the literature is whether fiscal decentralization can affect the government redistributive function and the income distribution within a country (for a notable exception, see Tselios et al. 2011). We believe this issue to be particularly relevant. The policy question is if efficiency-improving fiscal decentralization reforms may have undesirable equity consequences. This could happen, for example, if sub-national governments have incentives to spend less for social services and to move away from progressive taxation following a fiscal decentralization process. For example, fiscal decentralization may yield unintended economic consequences in countries that are characterized by high levels of overall income inequality and/or large regional economic and political disparities (e.g., Spain and Italy). In other words, fiscal 
decentralization - possibly introduced according to efficiency reasons - may affect overall income inequality through both direct and indirect channels. Direct effects may be triggered by changes in the progressivity of the tax system or in the composition of public expenditures. Indirect effects may be at work through a number of socio-economic factors (e.g. growth, stability, the degree of institutional development, the size of government intervention in the economy) that are likely to be affected by fiscal decentralization.

The aim of this paper is to shed some light on the relationship between fiscal decentralization and income inequality. The previous literature contains some attempts to capture the linkages between these two economic phenomena. However, no widespread consensus has emerged on the exact nature of the relationship, possibly because of different theoretical and empirical approaches and of some "confusion" around the inequality concept adopted. In fact, most previous studies have used this term without distinguishing between household income inequality (usually measured with the Gini index calculated using household income - e.g. Akai and Sakata 2005), regional economic disparities (usually calculated with the Theil index calculated using economic indicators such as the Gross Value Added or the unemployment rate - e.g. Beramendi 2003), and other types of within-country heterogeneity (e.g. preferences among individuals across regions, Oates 1972; ethnic fragmentation, Beramendi 2007).

In our analysis we study the first of these concepts, i.e. household income inequality measured at the national level by the Gini index. In recent years, many developed countries witnessed a significant evolution of their income distributions. In particular, in most OECD countries income inequality remained stable during the 1980s, but then steadily increased in the next two decades. After 2000, the picture is less clear (McCall and Percheski 2010). For instance, the UK and the USA show the highest increases, while in France and Belgium income inequality seems to have stabilized (Smeeding 2002; OECD 2008). As many countries are simultaneously embarked on active policies aimed at reducing income inequality and poverty (Galasso and Ravaillon 2000; Ravallion 1999, 2000; von Braun and Grote 2000; Rao 2002; Boex et al. 2005) as well as in fiscal decentralization reforms, it is important to clarify the extent to which these policy strategies interact with each other.

Economic theory suggests many ways through which the process of transfers of powers and resources to lower tiers of government could be linked to income inequality. The standard theoretical approach affirms that decentralization lowers the likelihood of redistribution amongst individuals (and regions), increasing income disparities at the national level (Stigler 1957; Musgrave 1959; Oates 1968, 1972; Brown and Oates 1987; Prud'homme 1995). Recent contributions argue instead that fiscal decentralization works as a commitment device, possibly exerting opposite effects at least on regional economic inequalities (Weingast 1995; McKinnon 1995; 1997; Qian and Weingast 1997; Bahl et al. 2002; Gil Canaleta et al. 2004). According to these models, sub-national governments can play an important role in generating a more balanced distribution of income across regions through (beneficial) interregional competition characterized by a responsible behaviour of local policymakers who try to 
satisfy their citizens' demand. The ratio of our analysis can be found, to some extent, in the need to verify the normative prescriptions about the optimal level of government that should pursue redistributive objectives in order to guarantee an overall horizontal equity criterion.

The relationship between fiscal decentralization and income inequality is the object of a few existing empirical studies in which the dominant strategy is to assume that decentralization affects inequality. In this vein, most authors analyze regional disparities (e.g. Ezcurra and Pascual 2008), others overall income inequality (e.g. Sepulveda and Martinez-Vasquez 2011). ${ }^{1}$ No consensus has emerged on the sign of the effect of decentralization on income inequality. While Tselios et al. (2011) and Sepulveda and Martinez-Vasquez (2011) show that decentralization lowers income inequality, Neyapti (2004) finds that the opposite effect is at work when the quality of the institutions is low. Morelli and Seaman (2007) argue that decentralization does not affect income distribution in the UK. A similarly wide range of results is found by the authors that investigate the effects on regional disparities (e.g. Ezcurra and Pascual 2008; Kim et al. 2003). The key point remains that: "our knowledge about the influence, if at all, of decentralization processes on interpersonal inequalities is extremely limited and patchy" (Tselios et al. 2011, p. 3).

Following this line of research, our paper investigates the effects of fiscal decentralization on household income distribution using aggregate data for a group of 23 OECD countries over the period 1971-2000. We pay particular attention to the quality of the fiscal decentralization data, using several measures based on different degrees of both expenditure and tax autonomy. Most previous crosscountry studies (e.g. Letelier 2005; Rodriguez-Pose and Ezcurra 2010; Sepulveda and MartinezVasquez 2011) make use of the Government Finance Statistics (GFS) data published by the International Monetary Fund (IMF). These data permit to build a measure of the degree of fiscal decentralization based on the share of sub-central expenditures (revenues) over consolidated public expenditures (revenues).

However, the use of such an index presents relevant shortcomings. The most relevant is that, although the GFS dataset has consistent definitions across countries over time, it ignores the effective degree of central government control and the real autonomy of sub-central governments over local tax rates, tax bases and expenditures decisions. Indeed, no distinction between locally determined own taxes, piggybacked and shared taxes is made; likewise, local expenditures that are mandated or spent on behalf of central government wrongly appear as sub-national expenditures. As a consequence, the degree of fiscal decentralization tends to be overestimated (Ebel and Yilmaz 2003; Rodden 2003; Stegarescu 2005; Casette and Paty 2010). In this vein, Rodden (2003) also warns that it is not fiscal decentralization per se that matters, but what form it takes.

Therefore, we follow the suggestion by Ezcurra and Pascual (2008, p. 1199), "in the future (...) it might be interesting to include different decentralization measures in the analysis in order to capture

\footnotetext{
${ }^{1}$ There are a few exceptions. Beramendi $(2003,2007)$ and Bodman and Hodge $(2010)$ tested whether the degree of
} income inequality within a country affects the incentives for fiscal decentralization. 
the various dimensions of the devolution processes". We use several measures of fiscal decentralization constructed by Stegarescu (2005) that allow for different degree of real autonomy of sub-national governments (see Section 3 for details). We adopt this approach because no single indicator is able to adequately capture the real level of fiscal decentralization of a country.

Our results are the following. A higher level of fiscal decentralization is associated with a more unequal distribution of income across individuals within a country. The use of different indexes highlights the importance of the nature of the decentralization process, since the effects of fiscal decentralization on overall income inequality are mainly driven by the tax side. Moreover, the effects are stronger if real autonomy over the decentralized taxes is given to the sub-central governments. The estimation of the models analyzing the effects of expenditure decentralization does not yield robust findings. However, there is a weak evidence of qualitatively similar effects when expenditures over which sub-central governments can exert real powers are taken into account. Our findings appear to fit well with the traditional theory of fiscal federalism (Stigler 1957; Musgrave 1959; Oates 1972) concerning the minimum role to be played by local governments with regards to redistributive policies. More generally, the results seem to confirm the important linkages between fiscal decentralization and equity issues despite the scarce attention of the previous empirical literature that mainly focused on efficiency-related considerations on fiscal decentralization.

The remainder of the paper is organized as follows. Section 2 contains a review of the theoretical and empirical literature on the relationship between fiscal decentralization and income inequality. Section 3 illustrates the variables and the empirical strategy used in our analysis. Section 4 presents and discusses the estimation results. Finally, section 5 concludes.

\section{Literature review}

\subsection{The theoretical framework}

The existing theories on the relationship between fiscal decentralization and income inequality offer a variety of hints on the type of effects that the fiscal decentralization process may exert on the income distribution within a nation. Prud'homme (1995) and Peterson (1995) affirm, for example, that fiscal decentralization could have regressive effects on income inequality, as a result of the weakening of the equalization role of central government. This mechanism could be reversed by the potential reduction of regional disparities triggered by the devolution of fiscal power to sub-national governments that might generate a more balanced distribution of resources across space (Qian and Weingast 1997).

All these considerations highlight the key role played by sub-national tiers of government in performing redistributive policies to address equity targets. The traditional theory of fiscal federalism (Oates 1968, 1972, 1999) is sceptical about the assignment of redistribution functions to local governments due to the following reasoning. The central government is considered to be the only 
institutional subject able to make interpersonal comparisons of individuals' well-being over the national territory. According to this approach, the pursuit of an overall horizontal equity principle calls for the withdrawal of decentralization, since local governments are likely to follow their own equity targets independently from each other with unfavourable effects on the overall income distribution within the country leading to some kind of "different treatment of equals". Therefore, the central government only can satisfy the horizontal equity criterion following equality principles (see also Musgrave 1959 and Steve 1976). ${ }^{2}$ In other words, decentralization is likely to weaken the capacity of the central government to play an equalizing role across individuals through social and territorial transfers; this in turn affects (and reduces) the ability of the country to achieve a more balanced distribution of income across citizens.

On the other hand, more recent contributions (Pauly 1973; Johnson 1988; Hayes and Slottje 1989; Wellish 2000; Ashworth et al. 2002; Bahl et al. 2002; Barr 2004) start to recognize the important role of sub-central units in implementing redistributive policies. The main reasoning is expressed by Tresch (2002) who states that an optimal model of fiscal federalism requires a context in which all levels of government can simultaneously maximize their welfare function without falling into the problem of "incompatible distributional objectives". ${ }^{3}$ This scheme then allows for a successful decentralization of the redistributive function as each level of government is engaged in the redistributive activity to meet the conditions of interpersonal equity that provide the maximum social welfare. Actually, a more equal distribution of income within the country may be enhanced only if there is no cross-border mobility that permits effective within-region redistribution. If, by contrast, interregional mobility is costless, the relocation of potential recipients and donor-tax payers could lower the effectiveness of local redistribution.

It should be noted that the potential (increasing) effect of fiscal decentralization on income inequality appears to be mediated by efficiency effects linked to decentralization. Assuming that subnational governments have an information advantage over central governments about the needs and preferences of their residents, local decision-makers may respond better and more efficiently to the desires of their citizens (Tiebout 1956; Oates 1972). As also argued by Morelli and Seaman (2007, p. 524), "devolution will increase equality if resources are utilized more efficiently than under a more centralized system".

\footnotetext{
${ }^{2}$ The principle of overall horizontal equity in a local context requires that the public sector as a whole - both local and central - should not discriminate between two individuals who are equal from a fiscal point of view even if they live in two different regions of the same country (according to the so-called "equal treatment of equals"). See Bordignon et al. (2006a, 2006b) for theoretical and empirical studies on the application of the principle of horizontal equity to the local context (i.e. "relative" horizontal equity criterion).

${ }^{3}$ Tresch (2002) solves this issue assuming that each government has the social welfare function of the lower tier of governmental unit (according to the institutional hierarchy) as its objective function, while only the last level of government has the welfare of its residents as argument of its objective function.
} 
To sum up, the theoretical contributions on the effects of fiscal decentralization on income inequality do not permit to unambiguously predict the sign of the effect at work. Thus, its assessment seems to be largely an empirical issue. ${ }^{4}$

\subsection{Empirical studies}

The empirical literature contains a number of contributions on the effects of fiscal decentralization on inequality, also in the light of valuable hints offered by the theoretical studies described above. However, there are extensive differences with regards to the kind of inequality that has been investigated. Some authors concentrate on the relationship between fiscal decentralization and income inequality (Beramendi 2003; Sepulveda and Martinez-Vasquez 2011), while others look at the relationship between the former and some measures of regional disparities (e.g. Gil Canaleta et al. 2004; Kim et al. 2003). Moreover, issues such as the nature of fiscal decentralization (i.e. revenue versus expenditure decentralization: see Rodden 2003; Rodriguez-Pose et al. 2009) and the degree of effective autonomy assigned to sub-central governments (determined by the legislative competencies and by the degree of power over spending, tax-raising, and debt-raising decisions - Stegarescu 2005, 2009) have been often overlooked, although they can play a crucial role.

The actual degree of fiscal autonomy granted to sub-national governments is particularly important. Assuming the reduction of income inequality to be a policy objective, sub-central governments may not be able to achieve it through their tax policies - e.g. with some form of race-tothe-bottom competition in order to attract more tax base or levying taxation with regressive effects as indirect taxes - as they generally do not have discretion over major tax bases. Yet, they may effectively influence the income distribution by acting on the expenditure side of the budget, over which they typically have a higher degree of autonomy (e.g., implementing pro-poor policies).

Most previous empirical studies make use of data that do not permit to distinguish expenditures/taxes over which sub-central governments have really autonomous decision powers. In particular, the level of fiscal decentralization is commonly approximated with the sub-national share of total government expenditure (see e.g. Ezcurra and Pascual 2008; Sepulveda and Martinez-Vazquez 2011), leaving out of the analysis the potential effects of any revenue decentralization process. Moreover, the common source for this data is the GFS database made by the IMF (e.g. Beramendi 2003; Ezcurra and Pascual 2008; Rodriguez-Pose and Ezcurra 2010). The use of such a measure presents relevant shortcomings and could affect the soundness of the studies that adopted it. Indeed, the share of local revenue (expenditure) over the same total (consolidated general government) revenue (expenditure) is not a sufficient condition to identify the effective degree of fiscal

\footnotetext{
${ }^{4} \mathrm{~A}$ different strand of the literature considers inequality to be among the forces that lead to fiscal decentralization processes, therefore reversing the direction of causality examined so far (e.g., Pommerehne 1977; Panizza 1999). However, these studies refer to different types of inequality, such as ethnic fractionalization, or regional disparities. Nevertheless, we deal with reverse causality issues in our empirical analysis (as explained in Section 3) and we also address potential endogeneity issues through a couple of robustness checks (see Section 4).
} 
decentralization. Key elements such as real autonomy, responsibility, power and control over tax/expenditure decisions are wrongly kept outside from this simple definition.

Due to these issues, it is not surprising to find that mixed results on the decentralizationinequality relationship arise from the empirical literature. For example, Beramendi (2003) finds that a higher degree of fiscal decentralization leads to more unequal distributions of income within the country as regions can take different (even opposite) decisions with regards to redistribution. However, this relation seems to be sensitive to the assumptions underpinning the different specifications adopted and it is not robust to endogeneity issues. Conversely, Sepulveda and Martinez-Vazquez (2011) point out that decentralization helps reducing income inequality. Accordingly, inequality-reducing social welfare expenditures seem to be more effectively implementable at the local level, basically in the presence of central redistribution programs financed by a large central public budget. Neyapti (2006) shows that revenue decentralization leads to increased inequality (measured by the Gini coefficient calculated on household incomes withincountry) in 54 countries, but when coupled with good governance it can reduce inequality. Tselios et al. (2011) claim that fiscal decentralization decreases interpersonal income inequality within regions by using regionally aggregated microeconomic data for more than 100,000 individuals in the European Union, although the precise effect depends on the level of development of each region. On the other hand, Morelli and Seaman (2007) find that decentralization has no impact on intra-regional inequality in the UK, suggesting that "many of the influences on inequality lie beyond the powers of the devolved institutions themselves" (p. 524).

A similar variety of results has been found by the authors concentrating on regional disparities. For instance, while Ezcurra and Pascual (2008) stress that decentralization may lower income inequality in developed countries, Rodriguez-Pose and Gill (2004) find the opposite.

To sum up, "although interregional and interpersonal inequalities are not unrelated (Kanbur and Venables 2005), ${ }^{5}$ a spawning literature on fiscal federalism has been concerned with the influence of decentralization and its changes on territories, but has shown relatively little interest on the implications for individuals" (Tselios et al. 2011, p. 4). The following section tries to fill this gap in the literature, offering an analysis of the effects of fiscal decentralization on household income inequality.

\section{The empirical strategy}

We employ data for 23 OECD countries over the period 1971-2000 to study the effect of fiscal decentralization on household income inequality. The choice of sample under investigation is dictated

\footnotetext{
5 Actually, the impact of fiscal decentralization on overall income inequality may depend on the relative importance of its two components (intra- and inter-jurisdictional/regional inequality). Such a hypothesis is certainly appealing, but cannot be directly assessed here, basically due to wide data limitations.
} 
by data availability, particularly because of the lack of fiscal decentralization data after 2000.6 We use seven different measures of decentralization reflecting both the taxes/expenditures differentiation, and the various degrees of autonomy given to sub-national governments (see below for details); this allows us to gain new insights into the issues at stake.

The empirical results are based on the following model:

$$
\operatorname{INEQ}_{i,[t-t+4]}=\alpha_{i, 0}+\alpha_{i, 1} F D_{i, t}+\beta_{i, j}^{\prime} \mathbf{Z}_{i, t}+u_{i, t}
$$

where $I N E Q_{i[t-t+4]}$ denotes the five-year averages of household income inequality (measured by the Gini index calculated using gross household income). ${ }^{7}$ The right hand side variables are all expressed as initial five-year periods values in order to address reverse causality issues (see Furceri and Zdienicka 2011). $F D_{i, t}$ stands for one of the seven different indexes of fiscal decentralization, used one at a time, depending on the specification; $\boldsymbol{Z}$ is a set of controls for income inequality: a) GDPPC is per capita GDP (both in level and squared to check for the Kuznets hypothesis); b) GOVSIZE captures the importance of the public sector in the economy (measured by the ratio of total government expenditure over GDP); c) OPEN is trade openness (measured as the sum of imports and exports divided by GDP); d) POPGR stands for population growth; e) EDUC is education (measured as the average years of primary education in the population). Country-fixed effects $\left(a_{i, 0}\right)$ are included, while $u_{i, t}$ is the disturbance term.

Fixed effects estimates are performed to control for country-specific time-invariant factors that may affect the relationship between income inequality and fiscal decentralization (e.g., institutional factors such as whether the country is federal). In addition, we test the robustness of the results estimating a number of alternative specifications to deal with the issues of reverse causality and potential endogeneity.

Equation (1) is estimated over five-year non-overlapping periods: 1971-1975, 1976-1980, 1981-1985, 1986-1990, 1991-1995, and 1996-2000. There are three main reasons for adopting this procedure. First, we neutralize the effects of cyclical fluctuations. Second, the income inequality yearly series contains missing values - a problem which is reduced by computing five-year averages (Easterly 1999; Higgins and Williamson 1999; Li and Reuveny 2003). Third, the quality of the inequality variable, which is potentially subject to measurement errors, is improved by taking the period averages (Sepulveda and Martinez-Vasquez 2011).

\footnotetext{
${ }^{6}$ We tried to extend the sample beyond 2000 but it proved impossible to do so. In particular, decentralization data from the IMF/Eurostat sources do not permit us to replicate the construction of the indexes built by Stegarescu (2005), also adopted in our analysis. Crucial information used to construct such indexes was contained in an OECD (1999) pioneering study that has not been updated since then.

${ }^{7}$ Measurement problems and limited data availability are a well-known problem in the literature. In particular, it is hard to find series with consistent definitions across a significant number of countries. In order to overcome these issues, in this study we take advantage of the Texas Inequality Project, that produced a rich dataset in terms of both countries and years covered.
} 
Table 1 contains some descriptive statistics of the variables used in the analysis. Details on the construction and sources of the variables can be found in the Appendix.

\section{Insert Table 1 about here}

It is worth describing the fiscal decentralization indexes built by Stegarescu (2005). Their use aims at solving the two main (and well-known) shortcomings of the IMF-GFS fiscal decentralization data, widely utilized in the previous empirical studies. First, the GFS data do not indicate "the extent to which the degree of decentralisation reflects the assignment of functions and resources to different levels of government and the extent to which it merely reflects the relative size of sub-central government activities" (Stegarescu 2005, p. 305). Second, they are "imperfect indicators of the share of public goods supplied by sub-central governments and of the actual degree of decentralisation of the public sector" (Stegarescu 2005, p. 305).

In our analysis, we use seven decentralization measures: three for tax revenue decentralization and four for expenditure decentralization. All indexes are based on some ratios of local revenues/expenditures over total national revenues/expenditures but they are much more informative and complete than those common used. On the tax side, the narrowest measure is TD1: this is the share of sub-central governments' own tax revenue over the total (national) tax revenue. This measure only takes into account the taxes over which local governments have complete autonomy. TD2 is a broader measure. It differs from TD1 because it also includes shared tax revenues. Finally, the broadest measure (TD3) is the "conventional" ratio between sub-central governments' total tax revenues and national total tax revenues. This index therefore includes the taxes that are collected at the local level but decided entirely by the central government. The actual degree of tax autonomy of sub-national governments increases passing from TD3 to TD1.

On the expenditure side, four different indexes are employed. ED1 is the broadest measure. It is calculated as the ratio of the sub-central governments' expenditure (minus the transfers to other levels of government) over the general government total expenditure (minus the intergovernmental transfers). Hence, ED1 reports only amounts spent directly by sub-national governments ("direct expenditure" according to Stegarescu 2005, p. 304) but not necessarily financed with own local resources, like intergovernmental transfers that are allocated to the recipient level. ED1S adds social security transfers to ED1. A narrower measure of expenditure decentralization is ED2: it is ED1 "adjusted for grants received from central government, thus taking into account all public expenses financed from formally own resources (self-financed expenditure", Stegarescu 2005, p. 304). ${ }^{8}$ Again, $E D 2 S$ includes social security transfers. It is worth noting that, in this case, the spending autonomy is to some extent more effective with ED2 than with ED1.

\footnotetext{
${ }^{8}$ In other words, ED2 does not include intergovernmental transfers received from other tiers of governments (mainly from the centre) as they are allocated to the grantor level.
} 
One shortcoming of all these indexes is the fact that there is no distinction between regional, local and other lower tiers governments: all sub-national units (i.e., regions, states, provinces, counties, territories or districts municipalities, local councils) are aggregated into a single group. This horizontal aggregation does not take into account the number of participating sub-central governments and the differences in competencies among them. A more correct measure of fiscal decentralization might consider the horizontal disaggregation of fiscal data by jurisdictions. Yet, this would create crosscountry comparability issues. Another shortcoming is that the expenditure indexes are uninformative about the types of expenditures included, i.e., about the spending composition and the policy mix. This is unfortunate, as it could be worth exploring, for instance, the different effects of education versus health expenditure decentralization. The lack of data with such a high level of details for a panel of countries poses some limitations to our present analysis. Despite these limitations, the quality of the information contained in the tax decentralization indexes is unquestionable. ${ }^{9}$

\section{Empirical results}

Table 2 reports the estimates of seven different specifications of the model in equation (1), one for each of the fiscal decentralization indexes used in the analysis.

Insert Table 2 about here

Table 2 highlights that the nature of fiscal decentralization matters. While results are inconclusive on the expenditure decentralization side, the first three columns suggest that tax decentralization directly affects household income inequality. The estimated coefficients of the three different tax indexes (TD1, $T D 2$, and TD3) are all positive and statistically significant (with estimates ranging between 0.10 and 0.17), meaning that higher degrees of tax decentralization are associated to more unequal distributions of income.

This latter finding seems to fit well with the traditional normative approach (Stigler 1957; Musgrave 1959; Oates 1972) according to which income redistribution and related policies should not be left to sub-central governments, as already explained in Section 2.1 and here summarized as follows: given a higher degree of decentralization, regions may pursue different redistribution strategies - possibly undermining the redistributive power of a nation - that may increase overall income inequality across individuals. An alternative explanation could be that the decentralization

\footnotetext{
${ }^{9}$ As for expenditure decentralization, comparable series have been produced by Gemmell et al. (2009), who follow Stegarescu (2005) and construct two different indicators that cover a larger time span (up to 2005). We use these data for robustness purposes in our empirical analysis (estimates are not reported in the paper). Actually, the advantage in terms of number of observations is negligible due to the fact that we would lose one country (namely, Japan) from our sample as $t$ is not included in the study by Gemmell et al. (2009).
} 
process may trigger a race-to-the-bottom competition across governments of the same level and lead to tax rates that are too low compared to the social optimum. ${ }^{10}$ This may imply lower revenues and resources to promote redistributive policies within each region, possibly worsening the household income distribution within a country.

Table 2 also demonstrates the importance of the effective powers given to sub-central governments in terms of autonomy over the decentralized taxes. Indeed, it emerges that the narrowest revenue measure (TD1), which best represents the real and effective degree of autonomy of local governments, has the largest effect (0.17) on household income inequality. The broadest index (TD3) shows the smallest - again positive - coefficient (0.10). This suggests than the worsening of the income distribution at the national level is likely to be more pronounced when the tax decentralization process involves "real" increases in local governments' autonomy, i.e. when sub-national tiers of government can independently decide and set their taxation policy (e.g., the tax base; the tax rate; the cases of exemptions and so on).

Our findings on the effects of tax decentralization are consistent with some of the previous literature. Sepulveda and Martinez-Vazquez (2011) claim indeed that decentralized tax policies are likely to directly affect disposable income distribution among individuals within a country. Fiscal decentralization promoted through the revenue side can reduce the progressivity of the tax system, altering the distribution of disposable income at the national level. This is due to the fact that subnational governments are mainly financed by indirect taxes, which tend to be more regressive, and property taxes, which are generally less progressive than the tax mix used by the central government. Both kinds of taxes mitigate the progressivity of the national tax system according to the conventional wisdom about the incidence of local taxes (see, e.g., Boex et al. 2005). Hence, revenue decentralization can exert a regressive effect on the household income distribution.

Nothing conclusive can be said with regards to expenditure decentralization. The coefficients associated to its four measures (ED1,ED1S, ED2, and ED2S) are not statistically significant at standard levels. This finding could also depend on the fact that expenditure decentralization approximates the degree of responsibility of local governments in defining public policies worse than the taxes indicators can do. Moreover, it is possible that different results on the expenditure side could be obtained with a more detailed disaggregation of local expenditures considering the expenditure composition and which type of expenditure is decentralized (e.g., health, welfare, education...). For example, the relationship between inequality and decentralization may be affected by the proportion of decentralized spending on education, given the known important role of education in reducing income disparities across individuals. However, controlling for the national level of education (as we do by including the EDUC variable) permits us to take into account this important variable in a way that overcomes the limitations of the data.

\footnotetext{
${ }^{10}$ This case is remarkably similar to the one in which different hierarchical government levels tax the same tax
} base, triggering horizontal externalities (see Keen and Kotsogiannis 2002 for a theoretical explanation). 
The rest of the explanatory variables carry interesting information that is robust across the seven different specifications. In particular, GDP significantly affects household income inequality in a nonlinear way, with positive coefficients associated with the level and negative with the squared term. This provides support for the Kuznets hypothesis, with a U-shaped relationship between income inequality and GDP. The other controls (education, openness, population growth and government size) present non-significant coefficients, although the sign of the estimates is consistent across the various specifications. Keeping in mind the statistical insignificance of the estimated coefficients, higher values of openness seem to increase inequality, while the opposite seems to hold for the educational level.

Government size is also negatively related to inequality. This result calls for a check of possible interactions between the level of fiscal decentralization (positively associated with inequality) and the importance of the public sector in the economy. The estimation of an alternative specification including an interaction term between fiscal decentralization and government size (not reported in the paper) suggests that only in two specifications out of seven (using the two broader measures of expenditure decentralization ED1 and ED1S) are the interaction effects on inequality significant. However, for average values of government size, the evidence still points towards a positive effect of decentralization on inequality. Results for the control variables are not affected.

The goodness of fit of the various specifications of the model measured by the R-squared is low, as it is often the case when using variables that describe income distributions. For this reason, we report the F-statistic for the joint statistical significance of all the explanatory variables of the model. In all cases, its values are reassuringly high. Moreover, the goodness of fit of the model increases in the dynamic specifications implemented for robustness purposes (see below).

To control for possible cross-sectional correlation, we re-estimate equation (1) using Feasible Generalised Least Squares (FGLS) techniques with fixed effects.

\section{Insert Table 3 about here}

Table 3 confirms the previous results on the positive relationship between fiscal decentralization mainly based on taxes - and household income inequality. Actually, the positive coefficients estimated for the two narrow measures of expenditure decentralization (ED2 and ED2S) are now significant, contrarily to the benchmark estimates. Once again, this stresses the importance of using decentralization measures that are able to discern among different degrees of autonomy granted to sub-central governments.

The last two robustness checks aim at dealing with potential endogeneity issues. Tables 4 and 5 report the estimates of our benchmark model modified as follows: all the variables are expressed as five-year averages and the lagged dependent variable is added to make the model dynamic. 
The results confirm the positive relationship between fiscal decentralization and household income inequality, and the measure of goodness of fit of the model is now notably higher. In particular, the decentralization coefficients are significant and positive (Table 4, fixed effects estimation) with two of the three tax decentralization indexes and with the two narrowest expenditure indexes (TD2-3 and ED2-2S, respectively). As for the system-GMM results (Table 5 - necessary due to the inconsistency of the fixed effects estimates that include the lagged dependent variable), the decentralization coefficients are positive in all cases, but never significant. We believe this to be due to the small time dimension of the panel (see Everaert and Pozzi 2007). In fact, Cameron and Trivedi (2005) warn that this kind of estimators applied to panels with a small number of units (countries in our case) leads to a large loss of efficiency. The coefficient of the lagged dependent variable is in all specifications close to 1 and statistically highly significant, showing the high inertia characterizing household income inequality.

To sum up, it seems that even controlling for reverse causality, cross-sectional correlation and endogeneity (and even allowing for a non-linear relationship), there is a strong evidence in favour of a positive relationship between fiscal decentralization and household income inequality. ${ }^{11}$ Although results vary depending on the fiscal decentralization measures used in the analysis, the evidence suggests that higher degrees of tax decentralization are indeed associated with higher levels of household income inequality measured by the Gini index.

\section{Conclusions}

Many countries recently and simultaneously embarked in active policies aimed at reducing poverty and income inequality as well as in fiscal decentralization reforms. Therefore, it seems important to clarify the extent to which these policy strategies interact with each other. The linkages between fiscal decentralization and income inequality represent an area of theoretical debate open to empirical investigation. A wide empirical literature has tried to shed some light on these complex interactions. However, clear evidence has not emerged due to contradictory estimates of the sign of the decentralization-inequality relationship. There is also some "confusion" over the proper inequality concept, as different definitions have been employed in order to describe the same phenomenon.

\footnotetext{
11 An additional robustness check in which we add period dummies to the benchmark specification (not reported) confirms the signs of the coefficients, but not their levels of statistical significance. However, as argued by Stegarescu (2009, p. 703): "we expect countries to be less exposed to common patterns of spatial correlation than, for example, subnational entities."
} 
Measurement issues, reverse causality and potential endogeneity are all additional possible explanations for this lack of undisputed results.

Our paper contributes to existing literature with an empirical analysis of the relationship between fiscal decentralization and household income inequality using a sample of 23 OECD countries for the period 1971-2000. Particular attention has been paid to the nature of fiscal decentralization, with the use of several measures better able to account for the various degrees of both expenditure and tax autonomy.

Our results underline the relevance of how fiscal decentralization is implemented and promoted expenditure versus tax side. The extent to which sub-central governments have real autonomy to determine the allocation of their expenditure or to raise their own revenue also appears to matter. Tax decentralization positively affects household income inequality. Therefore, a higher degree of power and responsibility on taxes assigned to sub-central governments is associated with a more unequal distribution of income across households within a country. On the other hand, expenditure decentralization is not associated with significant effects on income inequality. This implies that lowering the degree of tax decentralization (possibly avoiding some form of the race-to-the-bottom competition across local governments) seems to be the best strategy to pursue in order to improve income (re)distribution, while expenditure decentralization does not seem to be an effective tool. Therefore, local governments following their own equity targets through different tax instruments can unfavourably affect the distribution of household income nationally. Thus, it seems hard to combine the fiscal decentralization process and the equality principle, notwithstanding the potential efficiency gains of decentralization.

To conclude, the paper has some limitations which can be the object of further research should superior data become available. For example, extending the time span of the sample beyond 2000 could give us interesting hints related to the more recent developments in the fiscal decentralization processes. Moreover, while the classification of tax measures is quite detailed in representing the real level of tax autonomy of each typology, further efforts and improvements could be made in reference to the local expenditure side. This would imply breaking down sub-central expenditure by function and classification according to the degree of local discretion in legislation and execution. Finally, studying less developed countries could also prove interesting. 


\section{References}

Akai, N., Sakata, M. (2005). Fiscal Decentralization, Commitment and Regional Inequality: Evidence from State-level Cross-sectional Data for the United States. CIRJE Discussion Paper Series.

Ashworth, J., Heyndels, B., Smolders, C. (2002). Redistribution as a Local Public Good: An Empirical Test for Flemish Municipalities. Kyklos 55(1), 27-56.

Bahl, R., Martinez-Vazquez, J., Wallace, S. (2002). State and Local Government Choices in Fiscal Redistribution. National Tax Journal LV(4), 723-742.

Barr, N. (2004). The Economics of Welfare State, $4^{\text {th }}$ edition, Oxford, Oxford University Press.

Beramendi, P. (2003). Political Institutions and Income Inequality: The Case of Decentralization. Discussion Paper SP II 09, WZB.

Beramendi, P. (2007). Inequality and the territorial fragmentation of solidarity. International Organization 61:4, 783-820.

Bird, R., Wallich, C. (1993). Fiscal Decentralization and Intergovernmental Fiscal Relations in Transitional Economies: Towards a Systematic Framework of Analysis. Country Economics Department Working Paper, Washington DC:World Bank.

Bodman, P., Hodge, A. (2010). What drives fiscal decentralisation? Further assessing the role of income. Fiscal Studies 31(3), 373-404.

Boex, J., Heredera-Ortiz, E., Martinez-Vazquez, J., Timofeev, A., Yao, G. (2005). Fighting poverty through fiscal decentralization, Washington D.C., USAID.

Bordignon, M., Fontana, A., Peragine, V. (2006a). Il principio di equità orizzontale in un contesto federale. In F. Barca, F. Cappiello, L. Ravoni, M. Volpe (eds.), Federalismo, equità, sviluppo. I risultati delle politiche pubbliche analizzati e misurati dai Conti Pubblici Territoriali, Bologna, Il Mulino.

Bordignon, M., Fontana, A., Peragine, V. (2006b). Una applicazione empirica della misura dell'iniquità orizzontale in un contesto regionale. In F. Barca, F. Cappiello, L. Ravoni, M. Volpe (eds.), Federalismo, equità, sviluppo. I risultati delle politiche pubbliche analizzati e misurati dai Conti Pubblici Territoriali, Bologna, Il Mulino.

Brown, C.C., Oates, W.E. (1987). Assistance to the Poor in a Federal System. Journal of Public Economics $32,307-330$.

Cameron, C., Trivedi, P. (2005). Microeconomics: Methods and Applications, Cambridge University Press.

Casette, A., Paty, S. (2010). Fiscal decentralisation and the size of government: a European country empirical analysis. Public Choice 143(1-2), 173-189.

Easterly, W. (1999). Life during growth. Journal of Economic Growth 4, 239-275.

Ebel, R., Yilmaz, S. (2003). On the measurement and impact of fiscal decentralisation, in J. Alm and J. Martinez-Vazquez (Eds.), Public finance in developing countries: Essays in the honour of Richard M. Bird, Northhampton, Elgar, 101-20. 
Everaert, G., Pozzi, L. (2007). Bootstrap-based bias correction for dynamic panels. Journal of Economic Dynamics \& Control 31, 1160-1184.

Ezcurra, R., Pascual, P. (2008). Fiscal decentralization and regional disparities: evidence from several European Union countries. Environment and Planning A 40, 1185-1201.

Ezcurra, R., Rodríguez-Pose, A. (2010). Does decentralization matter for regional disparities? A crosscountry analysis. Journal of Economic Geography 10, 619-644.

Furceri, D., Zdzienicka, A. (2011). Financial Integration and Fiscal Policy. Mimeo.

Galasso, E., Ravallion, M. (2000). Distributional Outcomes of a Decentralized Welfare Program. Policy Research Working Paper 2316, World Bank, Washington.

Gemmell, N., Kneller, R., Sanz, I. (2009). Fiscal decentralization and economic growth in OECD countries: matching spending with revenue decentralization. Working Paper 6, Madrid: Instituto de Estudios Fiscales.

Gil Canaleta, C., Pascual Arzoz, P., Rapùn Gàrate, M. (2004). Regional economic disparities and decentralisation. Urban Studies 41, 71-94.

Gill, N., Rodriguez-Pose, A. (2004). Is there a global link between regional disparities and devolution? Environment and Planning A 36, 2097-2117.

Hayes, K., Slottje, D.J. (1989). The Efficacy of State and Local Government: Redistributional Policies. Public Finance Quarterly 17 (3), 281-303.

Higgins, M., Williamson, J. (1999). Explaining inequality the world round: Cohort size, Kuznets curves, and trade openness. NBER Paper N. 7224. Cambridge, National Bureau of Economic Research.

Johnson, W. (1988). Income Redistribution in a Federal System. American Economic Review 78(3), 570573.

Kanbur, R., Venables, A.J. (2005). Spatial inequality and development. In R. Kanbur, A.J. Venables (eds.), Spatial inequality and development. New York, Oxford University Press, 3-11.

Keen, M., Kotsogiannis, C. (2002). Does federalism lead to excessively high taxes? American Economic Review 92 (1), 363-370.

Kim, E., Hong, S.W., Ha, S.J. (2003). Impact of national development and decentralization policies on regional income disparity in Korea. Annals of Regional Science 37, 79-91.

Letelier, L. (2005). Explaining Fiscal Decentralization. Public Finance Review 33(2), 155-183.

Li, Q., Reuveny, R. (2003). Economic Openness, Democracy, and Income Inequality: An Empirical Analysis. Comparative Political Studies 36(5), 575-601.

Martinez-Vazquez, J., McNab, R. (1997). Fiscal decentralization, economic growth, and democratic governance. International Studies Program WP. Atlanta: Andrew Young School of Policy Studies, Georgia State University.

McCall, L., Percheski, C. (2010). Income inequality: new trends and research directions. Annual Review of Sociology 36, 329-347. 
McKinnon, R. (1995). Intergovernmental competition in Europe with and without a common currency. Journal of Policy Modelling 17, 463-478.

McKinnon, R. (1997). Market-preserving fiscal federalism in the American Monetary Union, in M. Blejer and T. Ter-Minassian (Eds.), Macroeconomic Dimensions of Public Finance: Essays in Honour of Vito Tanzi, London, Routledge, 73-93.

Morelli, C., Seaman, P. (2007). Devolution and inequality: a failure to create a community of equals? Transactions of the Institute of British Geographers 32, 523-538.

Musgrave, R.A. (1959). The theory of public finance: a study in public economy, New York, McGraw-Hill.

Neyapti, B. (2006). Revenue decentralization and income distribution. Economics Letters 92, 409-416.

Oates, W.E. (1968). The theory of public finance in a federal system. Canadian Journal of Economics 1, 3754.

Oates, W.E. (1972). Fiscal Federalism, New York, Harcourt Brace Jovanovich.

Oates, W.E. (1999). An essay on fiscal federalism. Journal of Economic Literature 37(3), 1120-1149.

OECD, (1999). Taxing Powers of State and Local Government, OECD Tax Policy Studies 1.

OECD, (2006). Fiscal autonomy of sub-central governments. Working Paper 2, Network on Fiscal Relations Across Levels of Government, OECD, Paris.

OECD, (2008). Growing unequal? Income distribution and poverty in OECD countries. OECD Publications, Paris.

OECD, (2009a). The Fiscal Autonomy of Sub-Central Governments: An Update. Working Paper 9, Network on Fiscal Relations Across Levels of Government, OECD, Paris.

OECD, (2009b). Tax and Grants: on the revenue mix of sub-central governments. Working Paper 7, Network on Fiscal Relations Across Levels of Government, OECD, Paris.

Panizza, U. (1999). On the determinants of fiscal centralization: theory and evidence. Journal of Public Economics 74(1), 97-139.

Pauly, M. (1973). Income Redistribution as a Local Public Good. Journal of Public Economics 2, 35-58.

Peterson, P. (1995). The Price of Federalism, Washington D.C., The Brookings Institution.

Pommerehne, W. (1977). Quantitative aspects of federalism: A study of six countries. In W. Oates (ed.), The political economy of fiscal federalism, Lexington, MA:D. C. Heath, 275-355.

Prud'homme, R. (1995). The dangers of decentralization. The World Bank Research Observer 10(2), 201220.

Qian, Y., Weingast, B.R. (1997). Federalism as a commitment to preserving market incentives. Journal of Economics Perspectives 11(4), 83-92.

Rao, M.G. (2002). Poverty Alleviation under Fiscal Decentralization, in M.G. Rao (ed.), Development, Poverty and Fiscal Policy. Decentralization of Institutions, New Delhi, Oxford University Press, 278298.

Ravallion, M. (1999). Are Poorer States Worse at Targeting Their Poor? World Bank, Washington. 
Ravaillon, M. (2000). Monitoring Targeting Performance When Decentralized Allocations to the Poor are Unobserved. Policy Research Working Paper 2080, World Bank, Washington.

Rodden, J (2003). Reviving leviathan: Fiscal federalism and the growth of government. International Organization 57, Fall, 695-729.

Rodríguez-Pose, A., Tijmstra, S.A.R., Bwire, A. (2009). Fiscal decentralisation, efficiency, and growth. Environment and Planning A 41, 2041-2062.

Sepulveda, C.F., Martinez-Vazquez, J. (2011). The consequences of fiscal decentralization on poverty and income equality. Environment and Planning C: Government and Policy 29, 321-343.

Smeeding, T. (2002). Globalization, inequality and the rich countries of the G-20: Evidence from the Luxembourg Income Study. Luxembourg Income Study Paper 320, LIS.

Stegarescu, D. (2005). Public sector decentralisation: Measurement concepts and recent international trends. Fiscal Studies 26(3), 301-333.

Stegarescu, D. (2009). The effects of economic and political integration on fiscal decentralization: Evidence from OECD countries. Canadian Journal of Economics 42:2, 694-718.

Steve, S. (1976). Lezioni di Scienza delle Finanze, Padova, Cedam.

Stigler, G. (1957). The Tenable Range of Functions of Local Government. Joint Economic Committee, Federal Expenditure Policy for Economic Growth and Stability, Washington, World Bank.

Von Braun, J., Grote, U. (2000). Does Decentralization Serve the Poor? Paper presented at IMF Conference on fiscal decentralization, 20-21 November 2000. Washington D.C.

Tiebout, C.M. (1956). A pure theory of local expenditures. Journal of Political Economy 64, 416-424.

Tresch, R.W. (2002). Public Finance: A Normative Theory, $2^{\text {nd }}$ edition, Elsevier Science, USA.

Tselios, V., Rodríguez-Pose, A., Pike, A.J., Tomaney, J., Torrisi, G. (2011). Income inequality, decentralisation and regional development in Western Europe. CEPR Discussion paper 8575.

Weingast, B.R. (1995). The Economic Role of Political Institutions: Market-Preserving Federalism and Economic Development. Journal of Law, Economics, \& Organization 11(1), 1-31.

Wellish, D. (2000). Theory of Public Finance in a Federal State. New York, Cambridge University Press.

World Bank (1999). Decentralization: Rethinking Government. World Development Report 1999/2000. Washington DC: World Bank. 
Tables and Figures

Table 1 - Descriptive statistics

\begin{tabular}{|c|c|c|c|c|c|c|c|c|}
\hline & & \multirow[t]{2}{*}{$\mathrm{N}$} & \multirow[t]{2}{*}{ Mean } & \multicolumn{3}{|c|}{ Standard deviation } & \multirow[t]{2}{*}{ Min. } & \multirow[t]{2}{*}{ Max } \\
\hline & & & & overall & between & within & & \\
\hline $\operatorname{INEQ}_{[t-t+4]}$ & & 129 & 35.04 & 3.68 & 3.11 & 2.10 & 27.17 & 45.22 \\
\hline \multirow[t]{7}{*}{$\mathrm{FD}_{[t]}:$} & TD1 & 138 & 18.19 & 16.40 & 16.41 & 3.06 & 0.00 & 58.68 \\
\hline & TD2 & 138 & 21.62 & 17.60 & 17.22 & 4.92 & 0.00 & 62.10 \\
\hline & TD3 & 138 & 22.64 & 17.14 & 16.72 & 4.93 & 0.05 & 62.10 \\
\hline & ED1 & 130 & 41.06 & 17.80 & 18.49 & 5.11 & 4.45 & 78.04 \\
\hline & ED1S & 130 & 31.80 & 15.13 & 15.59 & 3.54 & 3.37 & 62.62 \\
\hline & ED2 & 130 & 27.04 & 15.99 & 16.29 & 3.99 & 1.31 & 64.93 \\
\hline & $E D 2 S$ & 130 & 21.48 & 13.12 & 13.33 & 2.94 & 0.94 & 53.23 \\
\hline 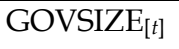 & & 138 & 9.47 & 2.42 & 2.35 & 0.73 & 3.47 & 16.69 \\
\hline $\mathrm{GDPPC}_{[t]}$ & & 138 & 21.94 & 6.41 & 4.88 & 4.25 & 8.87 & 48.32 \\
\hline $\operatorname{OPEN}_{[t]}$ & & 138 & 64.25 & 38.50 & 38.33 & 8.18 & 11.25 & 210.93 \\
\hline $\operatorname{POPGR}_{[t]}$ & & 138 & 0.82 & 2.05 & 0.84 & 1.88 & -0.57 & 23.47 \\
\hline $\mathrm{EDUC}_{[t]}$ & & 138 & 5.38 & 1.05 & 1.06 & 0.18 & 3.20 & 7.75 \\
\hline
\end{tabular}

Note: $t-t+4=$ five-year averages (1971-2000); $t=$ initial five-year period values; $\mathrm{N}=23$ countries (Australia, Austria, Belgium, Canada, Denmark, Finland, France, Germany, Greece, Iceland, Ireland, Italy, Japan, Luxembourg, Netherlands, New Zealand, Norway, Portugal, Spain, Sweden, Switzerland, United Kingdom, USA).

Source: Authors' elaborations 
Table 2 - Dependent variable: household income inequality (INEQ) - Fixed effects estimation

\begin{tabular}{lccccccc}
\hline & TD1 & TD2 & TD3 & $E D 1$ & $E D 1 S$ & $E D 2$ & $E D 2 S$ \\
\hline FD & $0.174^{* * *}$ & $0.103^{* * *}$ & $0.099^{* * *}$ & -0.000 & -0.026 & 0.076 & 0.085 \\
& $(3.04)$ & $(4.97)$ & $(4.44)$ & $(-0.01)$ & $(-0.32)$ & $(1.29)$ & $(1.01)$ \\
\hline GOVSIZE & $-0.462^{* *}$ & $-0.403^{*}$ & $-0.386^{*}$ & $-0.368^{*}$ & -0.350 & $-0.359^{*}$ & $-0.370^{*}$ \\
& $(-2.02)$ & $(-1.84)$ & $(-1.76)$ & $(-1.76)$ & $(-1.55)$ & $(-1.69)$ & $(-1.80)$ \\
\hline GDPPC & $0.770^{* * *}$ & $0.763^{* * *}$ & $0.782^{* * *}$ & $0.748^{* * *}$ & $0.742^{* * *}$ & $0.777^{* * *}$ & $0.766^{* * *}$ \\
& $(3.87)$ & $(3.85)$ & $(3.93)$ & $(3.56)$ & $(3.50)$ & $(3.64)$ & $(3.65)$ \\
\hline GDPPC^2 & $-0.010^{* * *}$ & $-0.009^{* * *}$ & $-0.010^{* * *}$ & $-0.009^{* * *}$ & $-0.009^{* * *}$ & $-0.010^{* * *}$ & $-0.010^{* * *}$ \\
& $(-3.13)$ & $(-3.07)$ & $(-3.14)$ & $(-2.71)$ & $(-2.67)$ & $(-2.82)$ & $(-2.83)$ \\
\hline OPEN & 0.024 & 0.020 & 0.019 & 0.034 & 0.035 & 0.029 & 0.033 \\
& $(1.49)$ & $(1.20)$ & $(1.11)$ & $(1.25)$ & $(1.28)$ & $(1.26)$ & $(1.40)$ \\
\hline POPGR & -0.013 & -0.006 & -0.004 & -0.018 & -0.021 & 0.006 & -0.005 \\
& $(-0.28)$ & $(-0.14)$ & $(-0.09)$ & $(-0.42)$ & $(-0.50)$ & $(0.12)$ & $(-0.12)$ \\
\hline EDUC & -2.038 & -1.982 & -2.084 & -1.994 & -1.894 & -2.471 & -2.238 \\
& $(-1.03)$ & $(-1.03)$ & $(-1.09)$ & $(-0.90)$ & $(-0.94)$ & $(-1.21)$ & $(-1.14)$ \\
\hline F-statistic & 129 & 129 & 129 & 122 & 122 & 122 & 122 \\
\hline Note t-statis. & $9.38^{* * *}$ & $13.74^{* * *}$ & $11.79^{* * *}$ & $6.91^{* * *}$ & $6.85^{* * *}$ & $7.12^{* * *}$ & $7.18^{* * *}$ \\
\hline
\end{tabular}

Note: $t$-statistics in parenthesis based on robust standard errors. ${ }^{* *},{ }^{* *}$, * denote significance at $1 \%, 5 \%$ and $10 \%$, respectively. Country dummies included but not reported. 
Table 3 - Dependent variable: household income inequality (INEQ) - FGLS estimation

\begin{tabular}{lccccccc}
\hline & TD1 & TD2 & TD3 & $E D 1$ & $E D 1 S$ & $E D 2$ & $E D 2 S$ \\
\hline FD & $0.131^{* * *}$ & $0.086^{* * *}$ & $0.093^{* * *}$ & -0.010 & -0.028 & $0.074^{* * *}$ & $0.097^{* * *}$ \\
& $(3.92)$ & $(4.54)$ & $(4.86)$ & $(-0.43)$ & $(-0.94)$ & $(2.77)$ & $(2.83)$ \\
\hline GOVSIZE & $-0.380^{* * *}$ & $-0.400^{* * *}$ & $-0.379^{* * *}$ & $-0.400^{* * *}$ & $-0.393^{* * *}$ & $-0.371^{* * *}$ & $-0.360^{* * *}$ \\
& $(-2.90)$ & $(-3.13)$ & $(-3.09)$ & $(-3.54)$ & $(-3.36)$ & $(-3.51)$ & $(-3.62)$ \\
\hline GDPPC & $0.633^{* * *}$ & $0.632^{* * *}$ & $0.668^{* * *}$ & $0.608^{* * *}$ & $0.605^{* * *}$ & $0.634^{* * *}$ & $0.652^{* * *}$ \\
& $(6.95)$ & $(7.18)$ & $(7.87)$ & $(6.72)$ & $(6.68)$ & $(7.05)$ & $(7.33)$ \\
\hline GDPPC^2 & $-0.008^{* * *}$ & $-0.008^{* * *}$ & $-0.008^{* * *}$ & $-0.007^{* * *}$ & $-0.007^{* * *}$ & $-0.008^{* * *}$ & $-0.008^{* * *}$ \\
& $(-4.92)$ & $(-5.09)$ & $(-5.60)$ & $(-4.70)$ & $(-4.67)$ & $(-4.88)$ & $(-5.23)$ \\
\hline OPEN & 0.015 & 0.011 & 0.007 & 0.011 & 0.011 & 0.014 & 0.015 \\
& $(1.08)$ & $(0.82)$ & $(0.55)$ & $(0.92)$ & $(0.87)$ & $(1.18)$ & $(1.28)$ \\
\hline POPGR & -0.018 & -0.016 & -0.016 & -0.033 & -0.034 & -0.010 & -0.015 \\
& $(-0.67)$ & $(-0.58)$ & $(-0.58)$ & $(-1.23)$ & $(-1.18)$ & $(-0.36)$ & $(-0.67)$ \\
\hline EDUC & -1.031 & -0.757 & -0.779 & -0.572 & -0.465 & -1.175 & -1.182 \\
& $(-1.36)$ & $(-1.03)$ & $(-1.16)$ & $(-0.71)$ & $(-0.59)$ & $(-1.50)$ & $(-1.62)$ \\
\hline Obs. & 128 & 128 & 128 & 121 & 121 & 121 & 121 \\
\hline Wald chi ${ }^{2}$ & $969.89^{* * *}$ & $1045.10^{* * *}$ & $1112.80^{* * *}$ & $1911.37^{* * *}$ & $1674.01^{* * *}$ & $3113.39^{* * *}$ & $2975.57^{* * *}$
\end{tabular}

Note: z-statistics in parenthesis based on robust standard errors. ${ }^{* *},{ }^{* *},{ }^{*}$ denote significance at $1 \%, 5 \%$ and $10 \%$, respectively. Country dummies included but not reported. 
Table 4 - Dependent variable: household income inequality (INEQ) - Dynamic fixed effects estimation

\begin{tabular}{lccccccc}
\hline & TD1 & TD2 & TD3 & $E D 1$ & $E D 1 S$ & $E D 2$ & $E D 2 S$ \\
\hline INEQ & $0.886^{* * *}$ & $0.873^{* * *}$ & $0.878^{* * *}$ & $1.007^{* * *}$ & $1.008^{* * *}$ & $0.973^{* * *}$ & $0.983^{* * *}$ \\
(lagged) & $(6.02)$ & $(5.68)$ & $(5.77)$ & $(6.45)$ & $(6.19)$ & $(6.26)$ & $(5.91)$ \\
\hline FD & 0.070 & $0.054^{* * *}$ & $0.054^{* * *}$ & 0.044 & 0.044 & $0.094^{* * *}$ & $0.089^{* *}$ \\
& $(1.53)$ & $(3.13)$ & $(2.97)$ & $(1.14)$ & $(0.78)$ & $(3.84)$ & $(2.38)$ \\
\hline GOVSIZE & 0.125 & 0.164 & 0.170 & 0.249 & 0.222 & $0.404^{* *}$ & 0.265 \\
& $(0.52)$ & $(0.67)$ & $(0.69)$ & $(1.02)$ & $(0.88)$ & $(2.07)$ & $(1.16)$ \\
\hline GDPPC & $0.609^{* * *}$ & $0.611^{* * *}$ & $0.608^{* * *}$ & $0.560^{* * *}$ & $0.562^{* * *}$ & $0.611^{* * *}$ & $0.549^{* * *}$ \\
& $(4.08)$ & $(4.25)$ & $(4.27)$ & $(3.87)$ & $(3.90)$ & $(5.20)$ & $(4.63)$ \\
\hline GDPPC^2 & $-0.009^{* * *}$ & $-0.009^{* * *}$ & $-0.009^{* * *}$ & $-0.008^{* * *}$ & $-0.009^{* * *}$ & $-0.009^{* * *}$ & $-0.008^{* * *}$ \\
& $(-3.98)$ & $(-4.08)$ & $(-4.08)$ & $(-3.86)$ & $(-3.92)$ & $(-5.12)$ & $(-4.57)$ \\
\hline OPEN & 0.015 & 0.015 & 0.014 & 0.019 & 0.020 & 0.013 & 0.019 \\
& $(0.62)$ & $(0.62)$ & $(0.58)$ & $(0.76)$ & $(0.79)$ & $(0.55)$ & $(0.87)$ \\
\hline POPGR & -0.022 & -0.005 & -0.001 & -0.040 & -0.063 & 0.042 & -0.059 \\
\hline ED2 & $(-0.14)$ & $(-0.03)$ & $(-0.01)$ & $(-0.24)$ & $(-0.41)$ & $(0.25)$ & $(-0.37)$ \\
\hline Note & -1.054 & -1.079 & -0.950 & -1.608 & -1.071 & -1.692 & -1.122 \\
& $(-0.68)$ & $(-0.22)$ & $(-0.64)$ & $(-0.81)$ & $(-0.61)$ & $(-1.17)$ & $(-0.83)$ \\
\hline & 106 & 106 & 106 & 100 & 100 & 100 & 100 \\
& 0.542 & 0.482 & 0.504 & 0.467 & 0.600 & 0.302 & 0.508 \\
\hline
\end{tabular}

Note: $t$-statistics in parenthesis based on robust standard errors. ${ }^{* *},{ }^{* *},{ }^{*}$ denote significance at $1 \%, 5 \%$ and $10 \%$, respectively. Country dummies included but not reported. 
Table 5 - Dependent variable: household income inequality (INEQ) - System GMM estimation

\begin{tabular}{|c|c|c|c|c|c|c|c|}
\hline & TD1 & TD2 & TD3 & ED1 & ED1S & ED2 & $E D 2 S$ \\
\hline INEQ & $1.359^{\star * *}$ & $1.345^{* * *}$ & $1.357^{* * *}$ & $1.346^{* \star *}$ & $1.421^{\text {*** }}$ & $1.423^{* * *}$ & $1.417^{* * *}$ \\
\hline (lagged) & (12.36) & (15.08) & (15.45) & $(6.27)$ & (5.99) & $(9.63)$ & $(8.97)$ \\
\hline \multirow[t]{2}{*}{$F D$} & 0.022 & 0.016 & 0.022 & 0.005 & 0.041 & 0.039 & 0.055 \\
\hline & $(0.31)$ & $(0.38)$ & $(0.55)$ & $(0.12)$ & $(0.45)$ & (1.17) & $(1.08)$ \\
\hline \multirow[t]{2}{*}{ GOVSIZE } & 0.159 & 0.253 & 0.255 & 0.261 & 0.269 & 0.317 & 0.286 \\
\hline & $(1.26)$ & (1.15) & (1.19) & $(1.09)$ & (1.37) & $(1.43)$ & (1.39) \\
\hline \multirow[t]{2}{*}{ GDPPC } & $0.425^{\star *}$ & $0.426^{\star *}$ & $0.404^{\star *}$ & $0.454^{\star * *}$ & $0.361^{*}$ & $0.323^{*}$ & $0.317^{\text {** }}$ \\
\hline & $(2.27)$ & (2.19) & $(2.14)$ & $(2.85)$ & $(1.67)$ & $(1.89)$ & $(2.02)$ \\
\hline \multirow[t]{2}{*}{$G D P P C^{\wedge} 2$} & $-0.007^{* * *}$ & $-0.007^{* * *}$ & $-0.007^{* * *}$ & $-0.008^{\star * *}$ & $-0.007^{* *}$ & $-0.006^{* *}$ & $-0.006^{\star *}$ \\
\hline & $(-2.84)$ & $(-2.65)$ & $(-2.60)$ & $(-3.75)$ & $(-2.31)$ & $(-2.38)$ & $(-2.59)$ \\
\hline \multirow[t]{2}{*}{ OPEN } & 0.011 & 0.010 & 0.011 & 0.010 & 0.015 & 0.014 & 0.014 \\
\hline & $(0.96)$ & $(1.34)$ & $(1.40)$ & $(1.11)$ & (1.12) & $(1.82)^{*}$ & $(1.76)^{*}$ \\
\hline \multirow[t]{2}{*}{ POPGR } & 0.015 & 0.029 & 0.023 & -0.246 & -0.263 & -0.176 & -0.232 \\
\hline & $(0.09)$ & $(0.17)$ & $(0.14)$ & $(-1.01)$ & $(-1.30)$ & $(-0.94)$ & $(-1.21)$ \\
\hline \multirow[t]{2}{*}{ EDUC } & 0.207 & $0.311^{\text {** }}$ & $0.325^{\star *}$ & $0.325^{* \star}$ & 0.192 & $0.404^{* *}$ & $0.267^{*}$ \\
\hline & $(0.41)$ & $(2.18)$ & $(2.33)$ & $(2.33)$ & $(0.61)$ & $(2.43)$ & (1.97) \\
\hline Obs. & 106 & 106 & 106 & 100 & 100 & 100 & 100 \\
\hline Hansen test & 0.495 & 0.469 & 0.489 & 0.331 & 0.491 & 0.492 & 0.562 \\
\hline
\end{tabular}

Note: $z$-statistics in parenthesis based on robust standard errors. ${ }^{* * *},{ }^{* *},{ }^{*}$ denote significance at $1 \%, 5 \%$ and $10 \%$, respectively. Country dummies included but not reported. $\sim$ p-value reported. 


\section{Appendix: variables, description and sources}

Household income inequality (INEQ). Gini index: estimates of gross household income inequality. Source: University of Texas Inequality Project EHII2008.

Fiscal decentralization (FD). Three tax revenue decentralization indexes (from the broader to the narrower measures: TD1, TD2, TD3), and four expenditure decentralization indexes (the broader measure: $E D 1$ - ED1S including social security transfers; the narrower measure ED2 - ED2S including social security transfers). Source: Stegarescu, D. (2005), "Public sector decentralization: Measurement concepts and recent international trends", Fiscal Studies 26, 301-333.

Government size (GOVSIZE). Government share of real Gross Domestic Product per capita. Source: Penn World Tables.

Education (EDUC). Average years of primary education. Source: Barro, R. and Lee, J.W. 2.0 07/2010.

Population (POPGR). Growth rates calculated from total population figures. Source: Penn World Tables.

GDP (GDPPC). Per capita GDP calculated from Purchasing Power Parity GDP (GDP growth GROWTH - has been calculated from that variable). Source: OECD Economic Outlook no. 87.

Openness (OPEN). Openness of the economy in current prices, measured as total trade (sum of import and export) as a percentage of GDP. Source: Penn World Tables. 